\title{
STATUS ANGINOSUS
}

\author{
BY \\ CORNELIO PAPP AND K. SHIRLEY SMITH \\ From the Cardiac Departments of the Charing Cross Hospital and the London Chest Hospital \\ Received, July 21, 1959
}

Nearly fifty years have passed since Obrastzow and Straschesko (1910) and Herrick (1912) showed that sudden obstruction of the coronary arteries was the basis of status anginosus. This term for the syndrome of worsening and incapacitating angina has of late years been considered obsolete and it has been replaced by such expressions as pre-infarction angina, acute coronary insufficiency, or cardiac infarction. In so far as it is employed today status anginosus denotes three different concepts: that of cardiac infarction in the sense of Herrick-increasing severity of attacks of angina terminating in "fatal status anginosus" (Fulton, 1956), that of frequently recurring anginal pain which may necessitate "the taking of nitroglycerin 50 times daily" (Master, 1958), or of intractable angina pectoris (Chevalier and Simon, 1959). Its use in this last sense is justified for it means an episodic clinical event becoming almost continuous through frequency of repetition (cf. status asthmaticus and status epilepticus). Although the functional basis of status anginosus is a reduced coronary flow, the term coronary insufficiency has been applied to such a variety of clinical conditions that it is today no more a diagnosis than angina pectoris (Scherf and Golbey, 1954). Even less fitting is the term acute coronary insufficiency (Horn et al., 1950) for this manifestly chronic malady. Admittedly, status anginosus ends generally in cardiac death, yet the clinical and electrocardiographic syndrome of cardiac infarction may be delayed for months or years, or it may not occur at all; thus pre-infarction angina (Reeves and Harrison, 1956) is a term that. only partly describes the condition.

The expression status anginosus is here applied to the clinical state in which there is frequently recurring anginal pain at rest, alleviated by trinitrin briefly or not at all, and indistinguishable from the pain of cardiac infarction or from its prodromal manifestations, but without the laboratory and electrocardiographic signs of classical cardiac infarction. Patients with this syndrome have coronary artery disease and have angina of effort of varying severity. Although this is disabling in some instances, it is less of a problem than the recurring nocturnal angina which necessitates heavy sedation. Anginal pain may interrupt meals, increasing the distress and impairing nutrition. Status anginosus comes in periods that may last for weeks during which the patient may have frequent attacks at rest during the day, but mostly at night. The symptoms suggest the imminence of infarction and this may happen in some; but others recover gradually and revert to their previous state of angina of effort and sporadic nocturnal angina. These periods recur and status anginosus may last intermittently for years; if the end is not a coronary catastrophe or sudden death, it is congestive heart failure.

We have been interested in the electrocardiographic features of these disorders and in their correlation with the clinical symptoms. Our aim has been to find out whether or not there is an electrocardiographic pattern characteristic of status anginosus, and if so, how this evolves from the patient's basic pattern, and what is its ultimate development.

\section{MATERIAL}

We have studied 20 patients in whom the leading clinical symptom was severe angina at rest, suggesting cardiac infarction but not followed by the electrocardiographic signs of $Q$ waves, 
elevated R-T segments, or deep T wave inversion. Since most of these patients had long-standing coronary disease the basic electrocardiogram was with few exceptions abnormal. A criterion for inclusion was a stable electrocardiogram over months or years with which comparison should be possible. Disorders in which the electrocardiogram might mimic the patterns of coronary disease such as electrolyte imbalance, severe ventricular hypertrophy (except in Case 3), bundle-branch block, pulmonary infarction, pericarditis, anæmia, valvular heart disease, and ectopic tachycardia were excluded, and so were patients having treatment by digitalis or quinidine. Many tracings were recorded after paroxysms of cardiac pain and compared with the basic cardiogram. The patients have been followed up clinically and electrocardiographically and those who are surviving are still under observation.

\section{Clinical Features}

The series comprised 16 men and 4 women; the ages ranged from 35 to 77 and more than half were over 60. Six had slight hypertension; two had severe essential hypertension, but one (Case 10) lost the electrocardiographic signs of severe left ventricular strain after successful sympathectomy.

TABLE I

Clinical and Cardiographic Data in 9 Fatal Cases of Status Anginosus

\begin{tabular}{|c|c|c|c|c|c|c|c|c|}
\hline \multirow[b]{2}{*}{$\begin{array}{l}\text { Case } \\
\text { No: }\end{array}$} & \multirow[b]{2}{*}{ Age/sex } & \multirow[b]{2}{*}{$\begin{array}{l}\text { Obser- } \\
\text { vation }\end{array}$} & \multirow[b]{2}{*}{$\begin{array}{c}\text { Coronary } \\
\text { symptoms } \\
\text { before S.A. }\end{array}$} & \multicolumn{3}{|c|}{ Status Anginosus } & \multicolumn{2}{|c|}{ Electrocardiogram } \\
\hline & & & & Duration & $\begin{array}{l}\text { Occur- } \\
\text { rence of } \\
\text { infarct }\end{array}$ & $\begin{array}{l}\text { Clinical } \\
\text { signs }\end{array}$ & $\begin{array}{c}\text { Before } \\
\text { status } \\
\text { anginosus }\end{array}$ & $\begin{array}{l}\text { During status } \\
\text { anginosus }\end{array}$ \\
\hline $1^{*}$ & $67 / F$ & $2 \frac{3}{4} \mathrm{yr}$. & $\begin{array}{l}\text { A.E. } \dagger \text { later } \\
\text { ant. sept. } \\
\text { infarct. }\end{array}$ & 4 months & Terminal & $\begin{array}{l}\text { Terminal } \\
\text { C.H.F. }\end{array}$ & $\begin{array}{l}\text { Chronic } \\
\text { ischæmia }\end{array}$ & $\begin{array}{l}\text { Subendocardial } \\
\text { ischæmia LI-II- } \\
\text { AVL-AVF-V3-V6 }\end{array}$ \\
\hline $2^{*}$ & $56 / \mathrm{M}$ & $5 \mathrm{mth}$. & $\begin{array}{l}\text { Ant. sept. } \\
\text { infarct. }\end{array}$ & $\begin{array}{c}3 \text { wk (1957) } \\
5 \text { mo (1959) }\end{array}$ & Terminal & $\begin{array}{l}\text { Terminal } \\
\text { L.V.F. }\end{array}$ & $\underset{\text { scar }}{\text { Ant. sept. }}$ & $\begin{array}{l}\text { Subendocardial } \\
\text { ischæmia LII-AVF- } \\
\text { V6 }\end{array}$ \\
\hline $3^{*}$ & $54 / \mathrm{M}$ & $6 \mathrm{mth}$ & A.E. & 5 days & $\begin{array}{l}\text { During } \\
\text { S.A. }\end{array}$ & $\begin{array}{l}\text { Hyper- } \\
\text { tensive } \\
\text { L.V.F. }\end{array}$ & $\begin{array}{l}\text { L.V. } \\
\text { strain }\end{array}$ & $\begin{array}{l}\text { Subendocardial } \\
\text { ischæmia V4-V7 }\end{array}$ \\
\hline 4 & $52 / \mathrm{M}$ & $1 \frac{1}{2} \mathrm{yr}$. & A.E. & $1 \frac{1}{2} \mathrm{yr}$ & Terminal & $\begin{array}{l}\text { Diabetes } \\
\text { periph. } \\
\text { art. scler. }\end{array}$ & $\begin{array}{c}\text { Chronic } \\
\text { ischæmia }\end{array}$ & $\begin{array}{l}\text { Subendocardial } \\
\text { ischæmia V6-V7- } \\
\text { gradual worsening }\end{array}$ \\
\hline 5 & $54 / M$ & $2 \mathrm{yr}$. & $\begin{array}{l}\text { A. E.., later } \\
\text { post. inf. }\end{array}$ & 4 wk. & $\begin{array}{l}\text { Died in } \\
\text { S.A. }\end{array}$ & $\begin{array}{l}\text { Terminal } \\
\text { L.V.F. }\end{array}$ & Post. scar. & $\begin{array}{l}\text { Subendocardial } \\
\text { ischæmia V4-V6- } \\
\text { gradual worsening }\end{array}$ \\
\hline 6 & $72 / \mathrm{M}$ & $8 \mathrm{mth}$. & Post. inf. & 3 wk. & After S.A. & L.V.F. & Post. scar. & $\begin{array}{l}\text { Subendocardial } \\
\text { ischæmia V5-V6; } \\
\text { later post. ant. inf. }\end{array}$ \\
\hline 7 & $73 / \mathrm{M}$ & $13 \mathrm{yr}$. & $\begin{array}{l}\text { Disabling } \\
\text { A.E. small } \\
\text { lat. inf. }\end{array}$ & 9 mth. & None & Nephrosis & Lat. scar. & $\begin{array}{l}\text { Subendocardial } \\
\text { ischæmia V3-V6 }\end{array}$ \\
\hline 8 & $45 / M$ & $10 \mathrm{mth}$. & A.E. & $10 \mathrm{mth}$. & $\begin{array}{l}\text { At the } \\
\text { begin- } \\
\text { ning of } \\
\text { S.A. }\end{array}$ & Obesity & Post. inf. & $\begin{array}{l}\text { Subendocardial } \\
\text { ischæmia V4-V6 } \\
\text { for } 5 \mathrm{mth} .\end{array}$ \\
\hline 9 & $72 / \mathrm{M}$ & $9 \mathrm{yr}$. & A.E. & $\begin{array}{c}4 \text { mo }(1950) \\
3 \text { wk }(1954) \\
\text { and }(1956)\end{array}$ & $\begin{array}{l}\text { Years } \\
\text { after } \\
\text { S.A. }\end{array}$ & $\begin{array}{l}\text { C.H.F. } \\
2 \text { mth. } \\
\text { before } \\
\text { death }\end{array}$ & Normal & $\begin{array}{l}\text { Subendocardial } \\
\text { ischæmia LII- } \\
\text { AVF-V6 } 4 \text { years; } \\
\text { later post. ant. inf. }\end{array}$ \\
\hline
\end{tabular}

* For necropsy report see text.

† A.E. = angina of effort. 
One had diabetes; he and another had peripheral arteriosclerosis. The clinical features are summarized in Tables I and II. One woman and eight men died. Congestive heart failure was the cause of death in five patients and in three of these it followed cardiac infarction. In five there was sudden death a few days after severe cardiac pain. Status anginosus extended over periods lasting from five days to ten months.

It is difficult to establish the beginning of the syndrome for it develops insidiously from angina of effort, increasing gradually in severity and interspersed with sporadic attacks of nocturnal angina, and ultimately reaching the state in which angina at rest and decubital angina become the main features. At this stage our patients required oral or parenteral pethidine for several nights a week and additional sedation with barbiturates. Case 10 needed morphine as well during the most severe attacks. These periods of relentlessly recurring night attacks alternated with weeks of relative quiet when light sedation was adequate. "Duration" therefore includes the periods of relative improvement after which further relapse occurred. Status anginosus followed closely

TABLE II

Clinical and Cardiographic Data in 11 Cases of Status Anginosus FOLLOWED UP AND STILL UNDER OBSERVATION

\begin{tabular}{|c|c|c|c|c|c|c|c|c|c|c|}
\hline \multirow[b]{2}{*}{$\begin{array}{l}\text { Case } \\
\text { No: }\end{array}$} & \multirow[b]{2}{*}{ Age/sex } & \multirow[b]{2}{*}{$\begin{array}{l}\text { Obser- } \\
\text { vation }\end{array}$} & \multirow[b]{2}{*}{$\begin{array}{l}\text { Coron. } \\
\text { symptoms } \\
\text { before } \\
\text { S.A. }\end{array}$} & \multicolumn{4}{|c|}{ Status Anginosus } & \multicolumn{3}{|c|}{ Electrocardiogram } \\
\hline & & & & Duration & $\begin{array}{l}\text { Occurrence } \\
\text { of infarct }\end{array}$ & $\underset{\text { signs }}{\text { Clinical }}$ & $\begin{array}{l}\text { Before } \\
\text { S.A. }\end{array}$ & $\begin{array}{l}\text { During } \\
\text { S.A. }\end{array}$ & $\begin{array}{l}\text { After } \\
\text { S.A. }\end{array}$ & Outcome \\
\hline 10 & $50 / \mathrm{F}$ & $12 \mathrm{yr}$. & A. at rest & $\begin{array}{c}1 \text { yr. (1947) } \\
4 \frac{1}{2} \text { yrs. } \\
\text { (1954 onw.) }\end{array}$ & None & $\begin{array}{l}\text { Hypert. } \\
\text { cured by } \\
\text { sympath- } \\
\text { ectomy }\end{array}$ & $\begin{array}{l}\text { L.V. strain. } \\
\text { None after } \\
\text { sympath- } \\
\text { ectomy }\end{array}$ & $\begin{array}{l}\text { Reversal of } \\
\text { T with } \\
\text { subendoc. } \\
\text { isch. V5- } \\
\text { V7 }\end{array}$ & $\begin{array}{l}\text { Normal T. } \\
\text { Subendo- } \\
\text { cardialisch. } \\
\text { less }\end{array}$ & $\begin{array}{l}\text { Improved } \\
\text { with radio } \\
\text { iodine }\end{array}$ \\
\hline 11 & $62 / M$ & $11 \mathrm{yr}$. & $\begin{array}{l}\text { Ant. sept. } \\
\text { inf. } 1948 . \\
\text { Well till } \\
1956\end{array}$ & 3 yr. & None & None & A/sep. scar & $\begin{array}{l}\text { Reversal of } \\
\text { TIII and } \\
\text { AVF with } \\
\text { subendoc. } \\
\text { ischæmia } \\
\text { LII-III- } \\
\text { AVF }\end{array}$ & T upright & $\begin{array}{l}\text { Improved } \\
\text { on thiou- } \\
\text { racil }\end{array}$ \\
\hline 12 & 61/M & $9 \mathrm{yr}$. & $\begin{array}{l}\text { A.E. ant. } \\
\text { sept. } \\
\text { ischæmia }\end{array}$ & 8 yr. & $\begin{array}{l}3 \text { yrs. } \\
\text { after S.A. }\end{array}$ & None & Normal & $\begin{array}{l}\text { Ant. sept. } \\
\text { isch. Later } \\
\text { subendoc. } \\
\text { ischæmia }\end{array}$ & No change & $\begin{array}{l}\text { Improved } \\
\text { on ipron- } \\
\text { iazid }\end{array}$ \\
\hline 13 & $58 / \mathrm{M}$ & $7 \mathrm{yr}$. & $\begin{array}{l}\text { Ant. sept. } \\
\text { inf. }\end{array}$ & $7 \mathrm{yr}$. & Before S.A. & None & $\begin{array}{l}\text { ant. sept. } \\
\text { inf. }\end{array}$ & $\begin{array}{l}\text { R.B.B.B. } \\
\text { Later } \\
\text { subend. } \\
\text { isch. }\end{array}$ & No change & $\begin{array}{l}\text { Sl. better } \\
\text { on thiou- } \\
\text { racil }\end{array}$ \\
\hline 14 & $64 / F$ & $5 \frac{1}{2}$ yr. & $\begin{array}{l}\text { Ant. lat. } \\
\text { inf. }\end{array}$ & $2 \frac{1}{2}$ mth. & $\begin{array}{l}2 \text { mo. after } \\
\text { S.A. }\end{array}$ & $\begin{array}{l}\text { Gallop. } \\
\text { No CHF }\end{array}$ & $\begin{array}{l}\text { Chron. } \\
\text { ischæmia }\end{array}$ & $\begin{array}{l}\text { Subendoc. } \\
\text { ischæmia } \\
\text { LII-V3-V5 }\end{array}$ & $\begin{array}{l}\text { Ant. sept. } \\
\text { inf. }\end{array}$ & No angina \\
\hline 15 & $62 / M$ & $2 \frac{1}{2}$ yr. & None & $3 \mathrm{mth}$. & $\begin{array}{l}3 \text { mths. } \\
\text { after S.A. }\end{array}$ & $\begin{array}{l}\text { Gallop. } \\
\text { No CHF }\end{array}$ & - & $\begin{array}{l}\text { Subendoc. } \\
\text { isch. Later } \\
\text { post. inf. }\end{array}$ & $\begin{array}{l}\text { Subendoc. } \\
\text { isch. } \\
\text { worse V2- } \\
\text { v5. Post. } \\
\text { scar. }\end{array}$ & No angina \\
\hline 16 & $77 / \mathbf{M}$ & $1 \mathrm{yr}$. & A.E. & 4 days & None & None & $\begin{array}{l}\text { Chronic } \\
\text { ischæmia }\end{array}$ & $\begin{array}{l}\text { Subend. isch. } \\
\text { V5-V6 }\end{array}$ & $\begin{array}{l}\text { As before } \\
\text { S.A. }\end{array}$ & A.E. \\
\hline 17 & $62 / \mathrm{M}$ & $1 \mathrm{yr}$. & A.E. & $2 \mathrm{mth}$. & None & None & $\begin{array}{l}\text { Post. lat. } \\
\text { ischæmia }\end{array}$ & $\begin{array}{l}\text { Subend. isch. } \\
\text { V5-V6 }\end{array}$ & $\begin{array}{l}\text { As before } \\
\text { S.A. }\end{array}$ & No angina \\
\hline 18 & $70 / F$ & $1 \mathrm{yr}$. & A.E. & $6 \frac{1}{2}$ mth. & None & None & Normal & $\begin{array}{l}\text { Subend, isch. } \\
\text { for mths. } \\
\text { V3-V6 }\end{array}$ & Normal & $\begin{array}{l}\text { Improved } \\
\text { on chloro- } \\
\text { thiazide }\end{array}$ \\
\hline 19 & $35 / \mathrm{M}$ & $1 \mathrm{yr}$. & None & $\begin{array}{l}21 \text { days- } \\
\text { none for } \\
5 \mathrm{w} \text {, then } \\
14 \text { days }\end{array}$ & After S.A. & None & Normal & $\begin{array}{l}\text { Doubtful } \\
\text { changes }\end{array}$ & $\begin{array}{l}\text { Post. lat. } \\
\text { inf. }\end{array}$ & No angina \\
\hline 20 & $55 / M$ & $21 \mathrm{yr}$. & None & $\begin{array}{l}3 \text { days } \\
\text { (1956) } \\
3 \text { days } \\
\text { (1957) }\end{array}$ & After S.A. & None & Normal & $\begin{array}{l}\text { Ac. injury } \\
\text { LI-AVL- } \\
\text { V6 }\end{array}$ & $\begin{array}{l}\text { ?High lat. } \\
\text { infarct. } \\
\text { Later } \\
\text { normal }\end{array}$ & No angina \\
\hline
\end{tabular}


upon cardiac infarction in two patients; one of these (Case 13) is still alive seven years after the infarct, having frequent anginal pain at rest; the second (Case 8) died suddenly in status anginosus which had persisted for ten months. Hæmorrhage from anticoagulant treatment may have precipitated death in Cases 3 and 8 . In Case 11 status anginosus appeared after a symptomless period of eight years that had followed extensive cardiac infarction and it has been present in varying intensity for more than two years.

Status anginosus led to cardiac infarction in ten patients. The interval varied between five days (Case 3) and three years (Case 12). In Case 19 three weeks of frequent angina were followed by five weeks of freedom; status anginosus then recurred and was succeeded within a week by cardiac infarction. In Case 14 status anginosus preceded the infarct for two months, and followed it for a fortnight until a second infarction took place; thereafter the pain subsided.

Status anginosus persisted in eight patients without infarction and these include the longest observations of 13 years (Case 7) and 12 years (Case 10). Case 7 was severely afflicted with angina of effort for 16 years yet led an active life; status anginosus began nine months before death which was caused by pulmonary œdema due to renal failure. There was never any suggestion of cardiac infaction. A woman (Case 10) with severe essential hypertension had status anginosus for one year before sympathectomy in 1948; after a successful operation she was free of angina for six years but since 1954 this has recurred and needed pethidine injections at least twice weekly. Case 12 who was in status anginosus for eight years had a subtotal thyroidectomy in 1952, stellate ganglionectomy in 1957, and finally pericardial poudrage in 1958 for the relief of angina. Though occasional patterns of ischæmia were seen in this cardiogram there was never any suggestion of a transmural infarct.

Clinical signs in this syndrome were few. Triple rhythm became a permanent feature in Cases

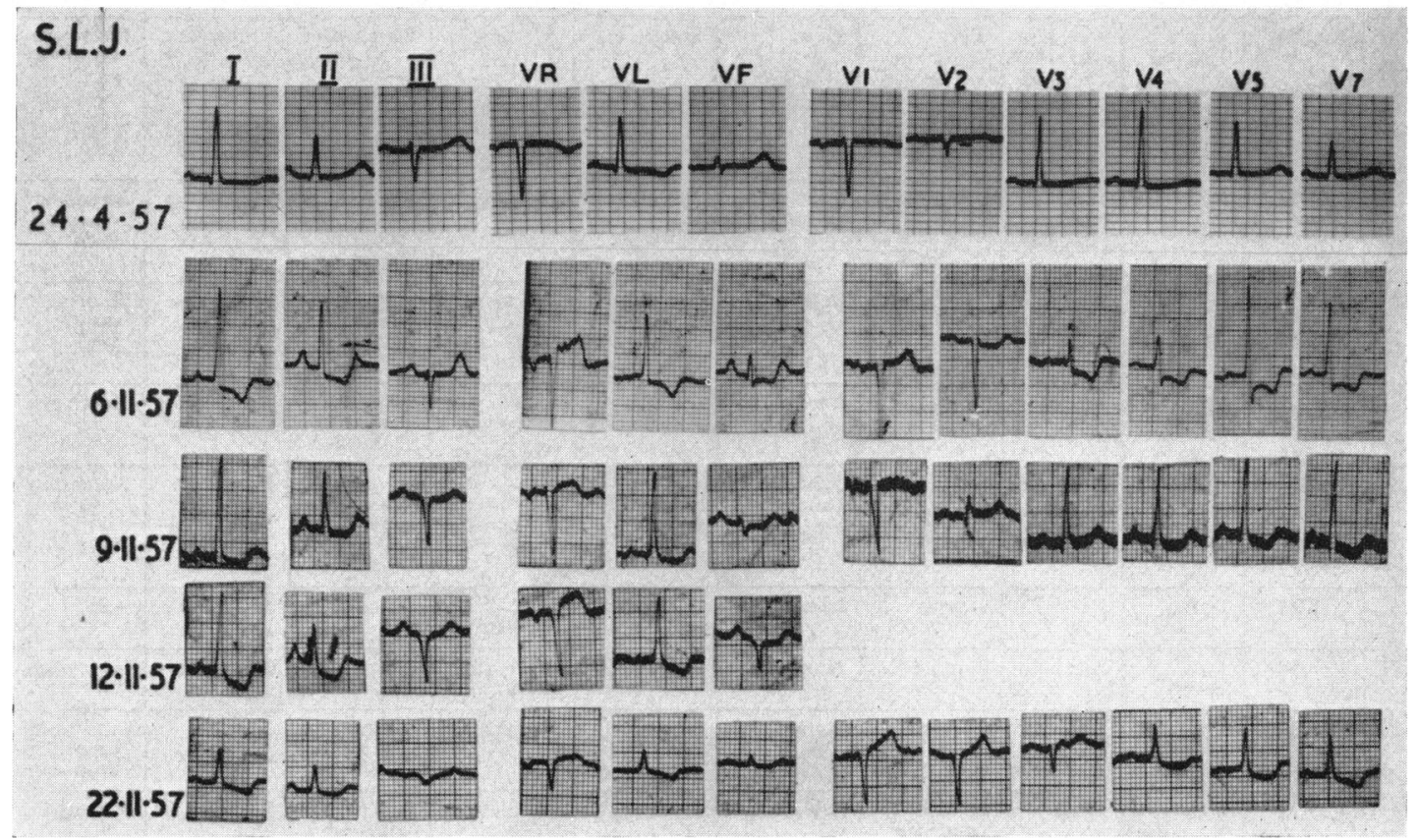

Fig. 1.-Serial electrocardiograms of Case 1, showing evolution of the pattern of subendocardial ischæmia out of the pattern of chronic ischæmia during status anginosus. Note sagging $R-T$ depression in standard and lateral chest leads, reciprocal $R-T$ elevation in aVR, and gradual reduction of voltage in $R$ in 1,11 , aVL, V5, and V7. Last record five days before death. Necropsy confirmation of infarction of the inner two-thirds of the left ventricular wall and papillary muscle. 


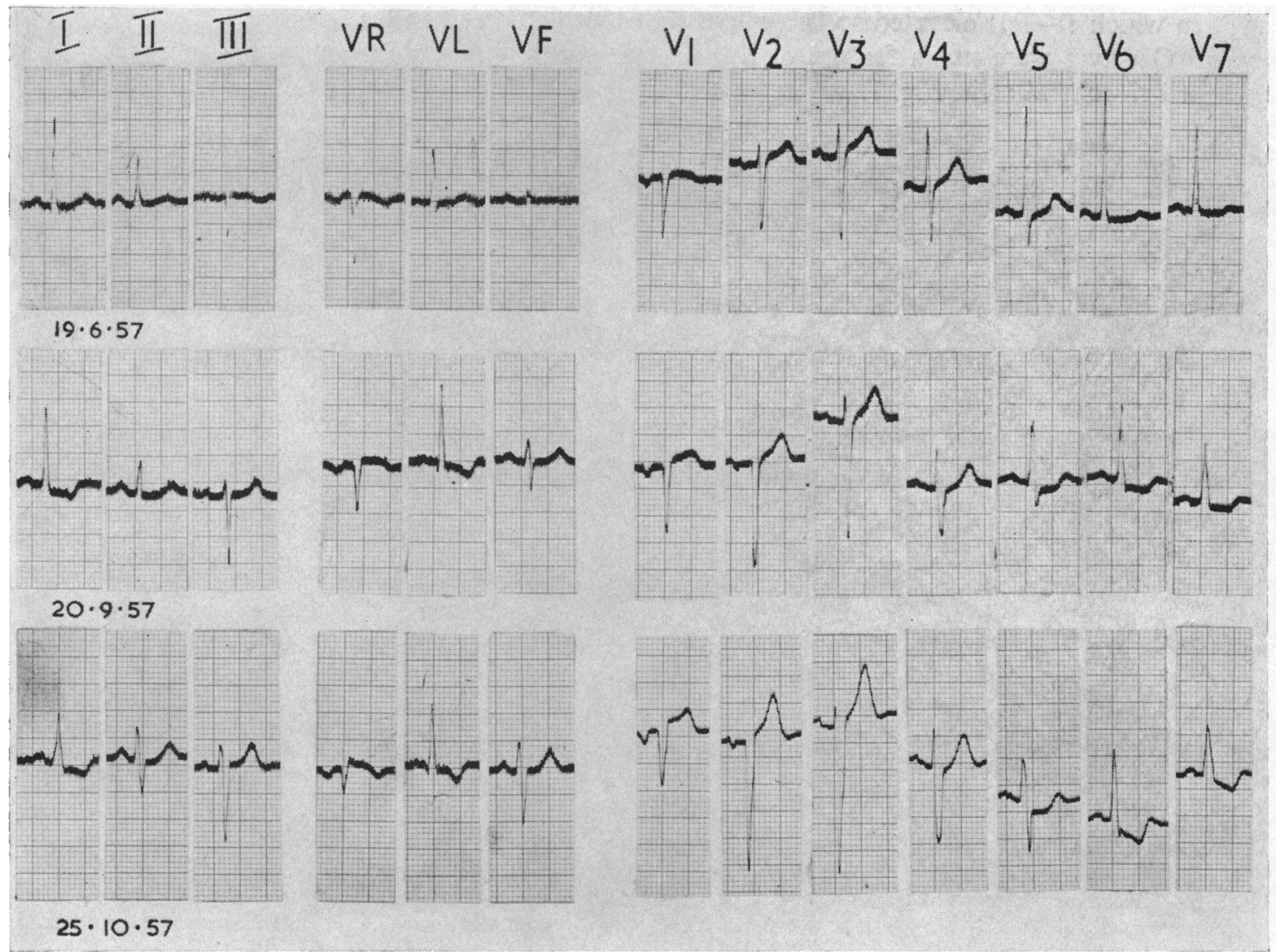

Fig. 2.- Serial cardiograms of Case 4. Disabling status anginosus lasting for 18 months. Last record three days before sudden death in cardiac pain, showing $3 \mathrm{~mm}$. R-T depression in V5-V6 of a sloping pattern (cf. Fig. 1).

14 and 15 but was not supported by any other signs of congestive heart failure; it could not be abolished by digitalis. Signs of congestive heart failure appeared one and two months before death in Case 6 and Case 7, while in Cases 1, 2, and 9 pulmonary œdema was the prelude to death.

\section{Electrocardiographic Patterns}

The dominant feature in 14 out of 20 patients was depression of the $R-T$ segment ranging from 2 to $6 \mathrm{~mm}$. in more than two leads, recognized for long as a sign of subendocardial ischæmia or infarction (Master et al., 1941; Price and Janes, 1943; Yu and Stewart, 1950; Levine and Ford, 1950; Cook et al., 1958; Levine, 1958). It was not only the depth of the depression but the shape of the depressed R-T segment that was observed to be characteristic in our series. This pattern was best seen in the lateral chest leads (V5-V7) in which the descending limb of $R$ ends well below the $\mathbf{P}-\mathbf{R}$ segment and continues in a short straight slope downwards. It then abruptly turns upward to reach the iso-electric level (Fig. 1, 2, 3, and 4). This sudden turning point could be mistaken for an inverted $T$ wave, were it not that comparison with the $R-T$ segment in anterior chest leads showed that the T wave was diphasic with its peak above the iso-electric line in V5 and V7. This squarish depression may evolve out of a convex $R-T$ segment when left ventricular hypertrophy is associated, later assuming the concave form (Fig. 5).

Though the changes were best seen in the chest leads they appeared to a lesser extent in the standard and limb leads, i.e. in leads I, II, and aVL. However, the limb lead most diagnostic is 
aVR in which R-T is elevated to the extent that it is depressed in lead I (Fig. 1 and 2). Pathological $\mathrm{Q}$ waves were not a feature of this pattern; they were never seen except when they were present beforehand as in Fig. 1.

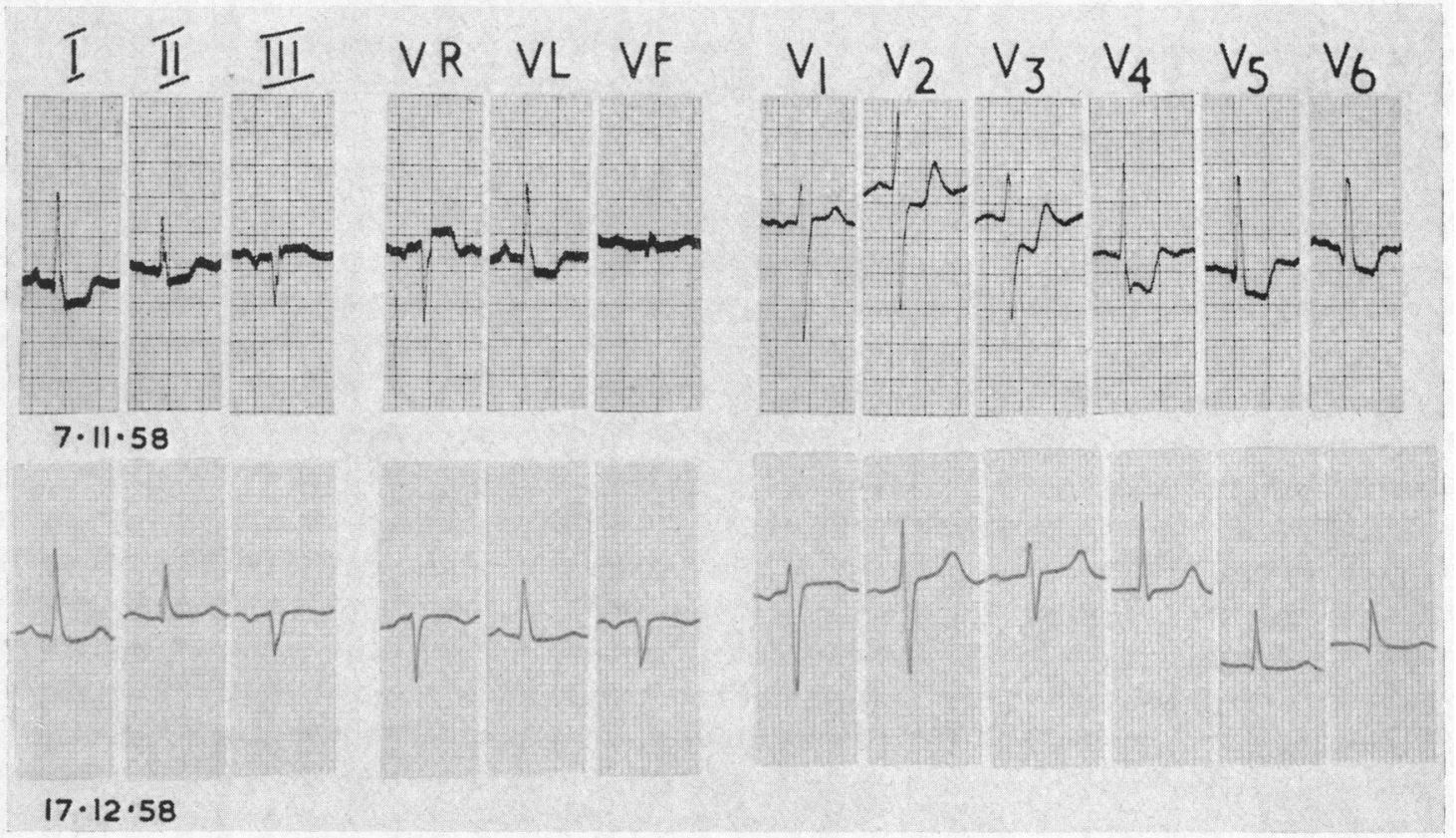

Fig. 3.-Electrocardiograms of Case 18. Subendocardial infarction pattern persisting for one month during status anginosus followed by reversion to normal. Cardiac pain persisted for some time with a normal resting record, but improved subsequently.

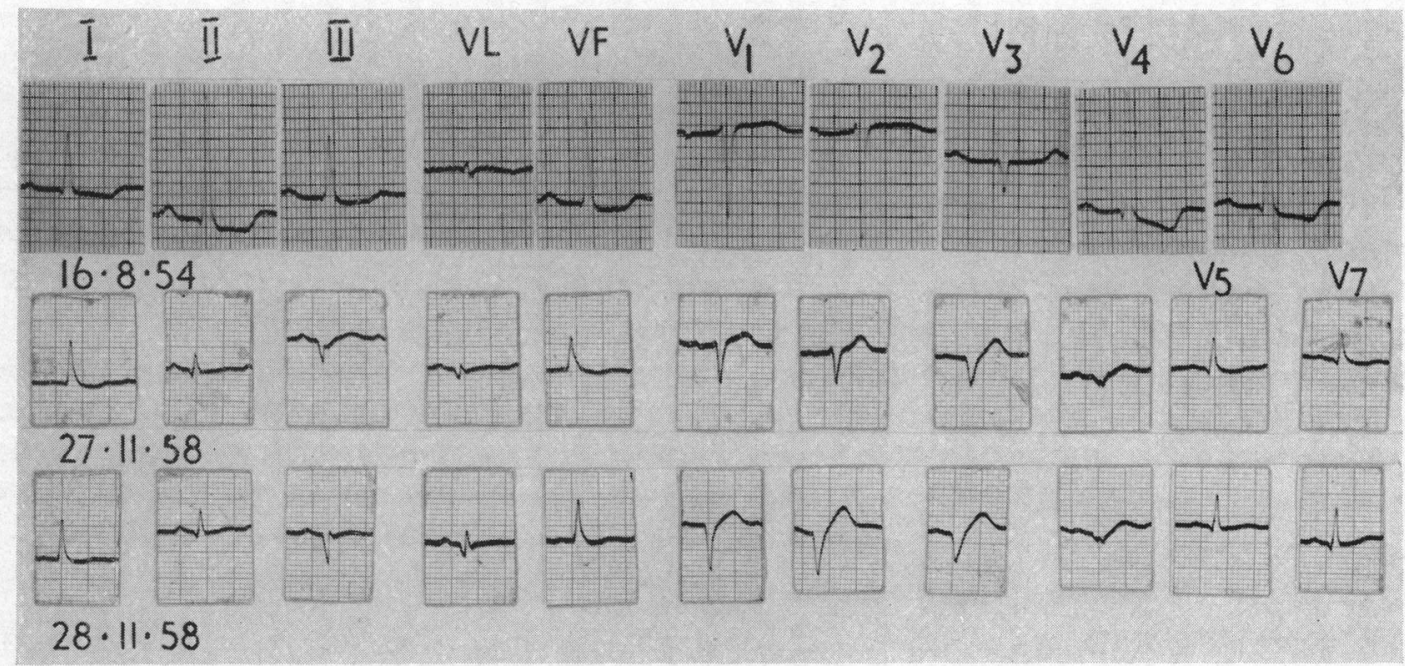

FIG. 4.-Serial electrocardiograms of Case 9. Square R-T depression in lead II, V4, and V6 during status anginosus. Four years later pattern of postero-anterior infarct: note leads III, aVL, and V4. Died of congestive heart failure about two months after last record. 


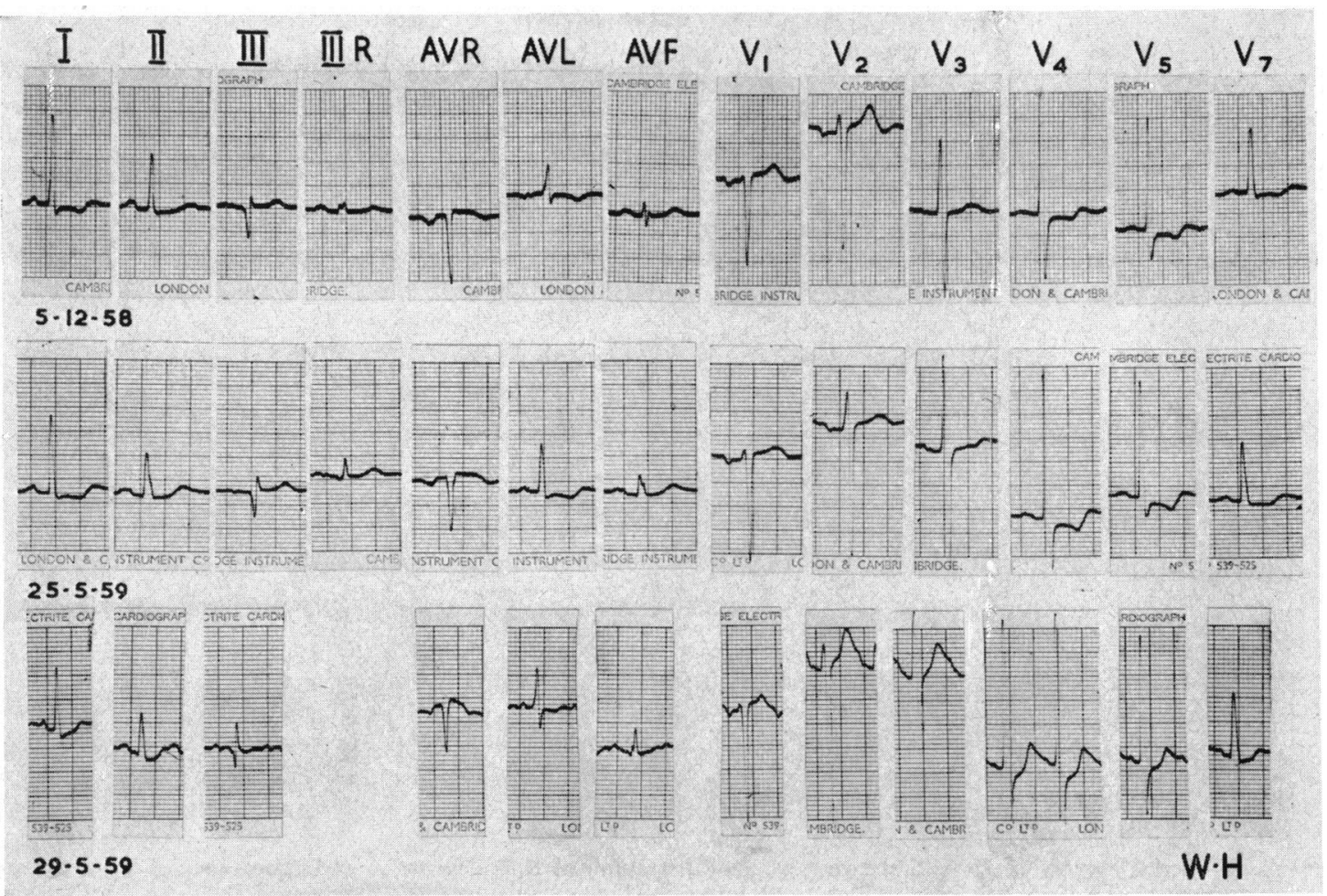

FIG. 5.-Subendocardial infarction pattern evolving out of the pattern of left ventricular strain in Case 3. Deepening $R-T$ depression in leads I, II, V4, and V5 with increasing $R-T$ elevation in aVR; transformation of convex R-T segment of left ventricular strain into the square $R-T$ pattern of subendocardial infarction in V4-V5. Last record two days before death.

Similar changes in posterior leads were rare. Our only example was in Case 2 (Fig. 6) in which an R-T depression in leads I, II, III, and aVF developed when status anginosus became worse; it deepened three days before death while a doubtful $Q$ wave appeared in V5. Contrary to the records in which subendocardial ischæmia was most prominent in lateral leads, there was no $R-T$ elevation in aVR in this record of postero-basal subendocardial ischæmia.

Diminution of $\mathrm{R}$ voltage, emphasized as an important feature by Cook et al. (1958), was prominent in three patients who died (Fig. 1 and 2). It was not seen in the others.

The pattern has much affinity with the square $R-T$ depression of the positive exercise test in angina; in fact, it could be called a fixed exercise test-pattern. It also much resembles the effect of digitalis, but in this the Q-T is shortened whereas this interval is prolonged or within normal limits in coronary disease. Once the pattern is established it can not be exaggerated by digitalis. Marked R-T depression in V2-V3 sometimes appears as a reciprocal effect during the acute stage of posterior infarction. It may then be impossible to say if anterior subendocardial infarction has also taken place: if it has, the pattern will persist during the deep $\mathrm{T}$ phase of posterior infarction (Fig. 7).

The cardiographic features of subendocardial ischæmia developed out of those of posterior infarction (Fig. 7) in three patients, out of a pattern of chronic ischæmia (Fig. 2) in three, and out of an extensive anterior infarction in two patients (Fig. 6 and 8). On six occasions the subendocardial ischæmia patterns evolved from those of anterolateral and anteroseptal subepicardial electrocardiograms as in Fig. 1; evolution out of a pattern denoting left ventricular strain was seen 


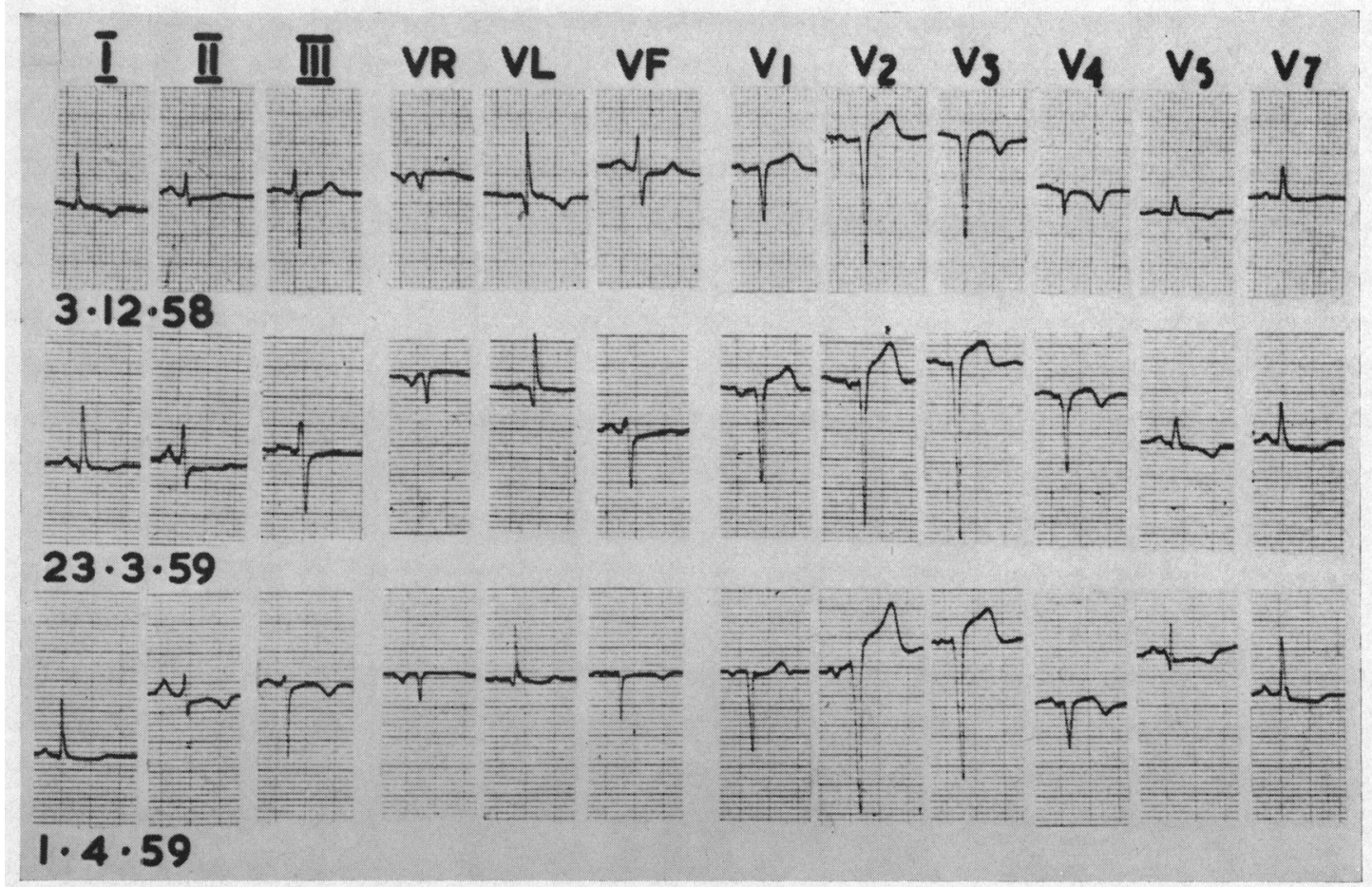

FIG. 6.-Serial records of Case 2, showing gradual deepening of R-T depression and appearance of $T$ inversion in posterior and lateral leads, without reciprocal R-T elevation in aVR. Tracing of $1 / 4 / 59$ in final stages of status anginosus, four days before death. Extensive old anteroseptal scar. Necropsy showed subendocardial infarcts in the posteroseptal areas of left ventricle.

in one patient (Fig. 5). The curves of subendocardial ischæmia reverted to near normal in two patients as illustrated in Fig. 3; they remained unchanged or became more pronounced in seven (Fig. 1, 2, and 8). Transformation of the subendocardial pattern into that of chronic ischæmia was observed in four instances, while evolution into tracings of postero-anterior infarction (Fig. 4) occurred in two patients. The latter both died and so did seven out of the nine in whom the pattern persisted or became more conspicuous. This particular pattern has been seen to exist for six days, eleven days, three weeks, one month, seven weeks, and five months before death. Depression of R-T deepened a few days before death in four patients in whom cardiograms were recorded at this stage, but $\mathrm{Q}$ waves did not appear in any of these records.

In 2 patients out of 20 (Cases 10 and 11) the record showed reversal of direction of the $T$ waves in anteroseptal and posterior leads respectively. These changes were independent of the presence or absence of pain at the time of recording. In Case 11 the posterior changes became later permanent and at this time a $1 \frac{1}{2}-\mathrm{mm}$. R-T depression developed in posterior and lateral leads with reciprocal elevation in aVR (Fig. 8).

An acute injury pattern in anterolateral leads which soon reverted to normal was seen in one patient only (Case 20). It appeared twice at four-monthly intervals after sustained attacks of nocturnal angina. Small changes in aVL which persisted when the cardiogram became otherwise normal suggested that he may have had a high lateral infarction.

An electrocardiogram with so little change that it could be regarded as within normal limits was recorded during status anginosus in one patient only (Case 19). He was the one in whom a symptomless period of five weeks elapsed between this state and posterior infarction. 


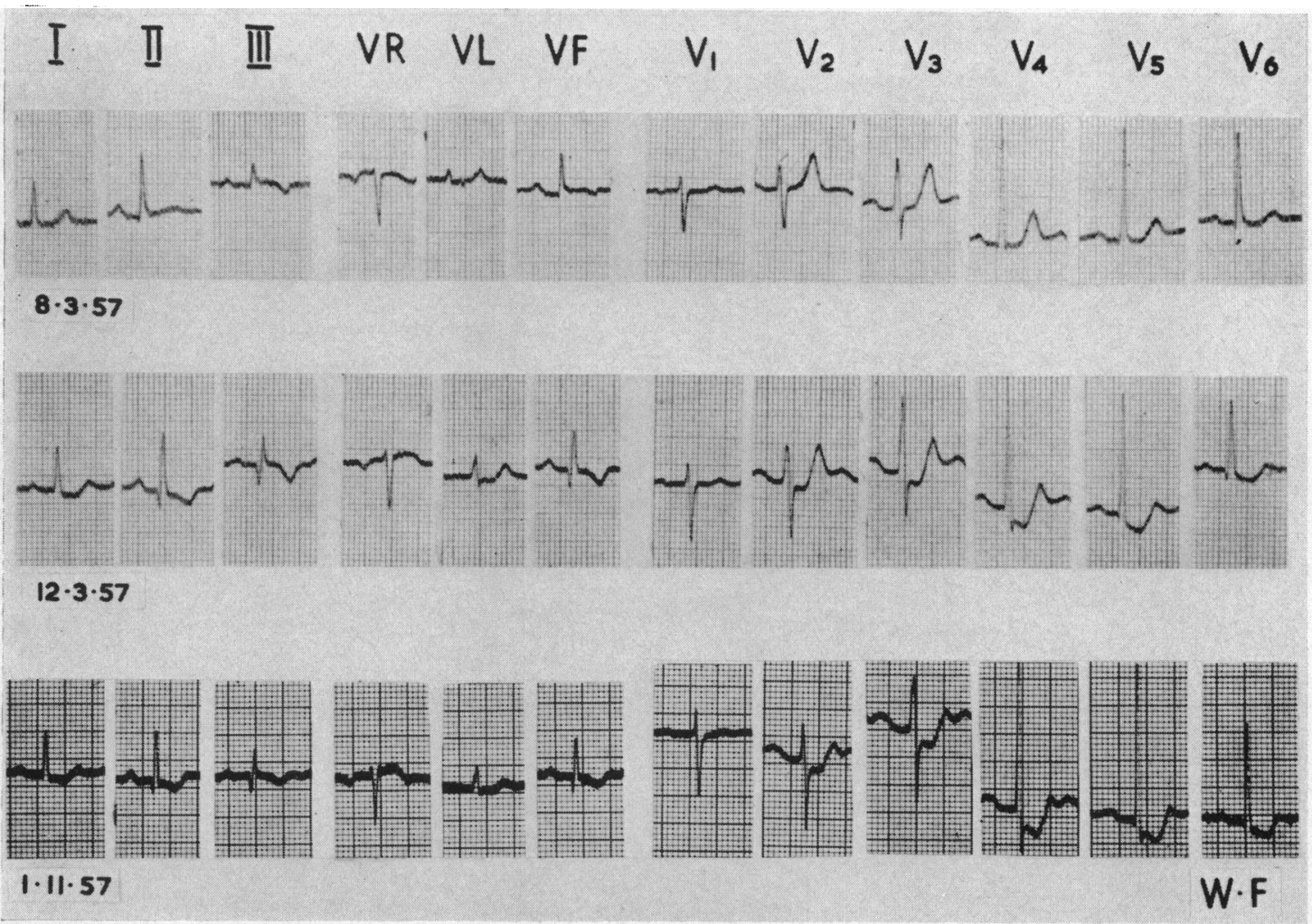

FIG. 7.- Serial tracings of Case 15. Status anginosus leading to posterior infarction. Extensive subendocardial infarction pattern followed and persisted after the healing of posterior infarct. It was therefore not a reciprocal effect.

\section{FindingS AT NECROPSY}

Detailed post-mortem studies were available in the following three cases showing the subendocardial ischæmia pattern.

Case 1. The heart weighed $285 \mathrm{~g}$. The pericardium appeared normal. In the myocardium there was evidence of a recent infarct involving the anterior wall, mainly of the left ventricle and the apex, with underlying endomural thrombus over an area of $4 \mathrm{~cm}$. in diameter. The infarction involved the inner two-thirds of the wall of the left ventricle extending into the papillary muscle of the mitral valve. In addition there was evidence of previous infarction in the interventricular septum with organization and fibrosis. There was a severe degree of atheroma affecting both coronary arteries within $3 \mathrm{~cm}$. of their origin. The walls were calcified and the lumen had been reduced to pin point size. No recent thrombus could be found.

Case 2. There was a scar of an old anteroseptal infarct in the left ventricle giving rise to aneurysmal dilatation. The entire posteroseptal region showed widespread mottling caused by recent myocardial infarction. There was severe atheroma of both coronary arteries reducing their lumen to pin point. The right coronary artery was occluded by recent thrombus $2 \mathrm{~cm}$. from its origin. Microscopical section of the posterior wall of the left ventricle showed an extensive recent myocardial infarct which involved the inner half of the thickness of the myocardial wall (Fig. 9). The main bulk of the lesion consisted of necrotic cardiac muscle, showing preservation of structure but without nuclei and without inflammatory infiltration. At the periphery of this area there was a dense polymorphonuclear infiltration beyond which the infarcted area extended as a zone of hyaline muscle fibres which had lost their nuclei but were infiltrated by a few polymorphonuclear leucocytes. The endocardium was intact and deep to it was a band of intact muscle fibres not more than two or three cells thick. There was no mural thrombus and no evidence of organization of the infarct. 


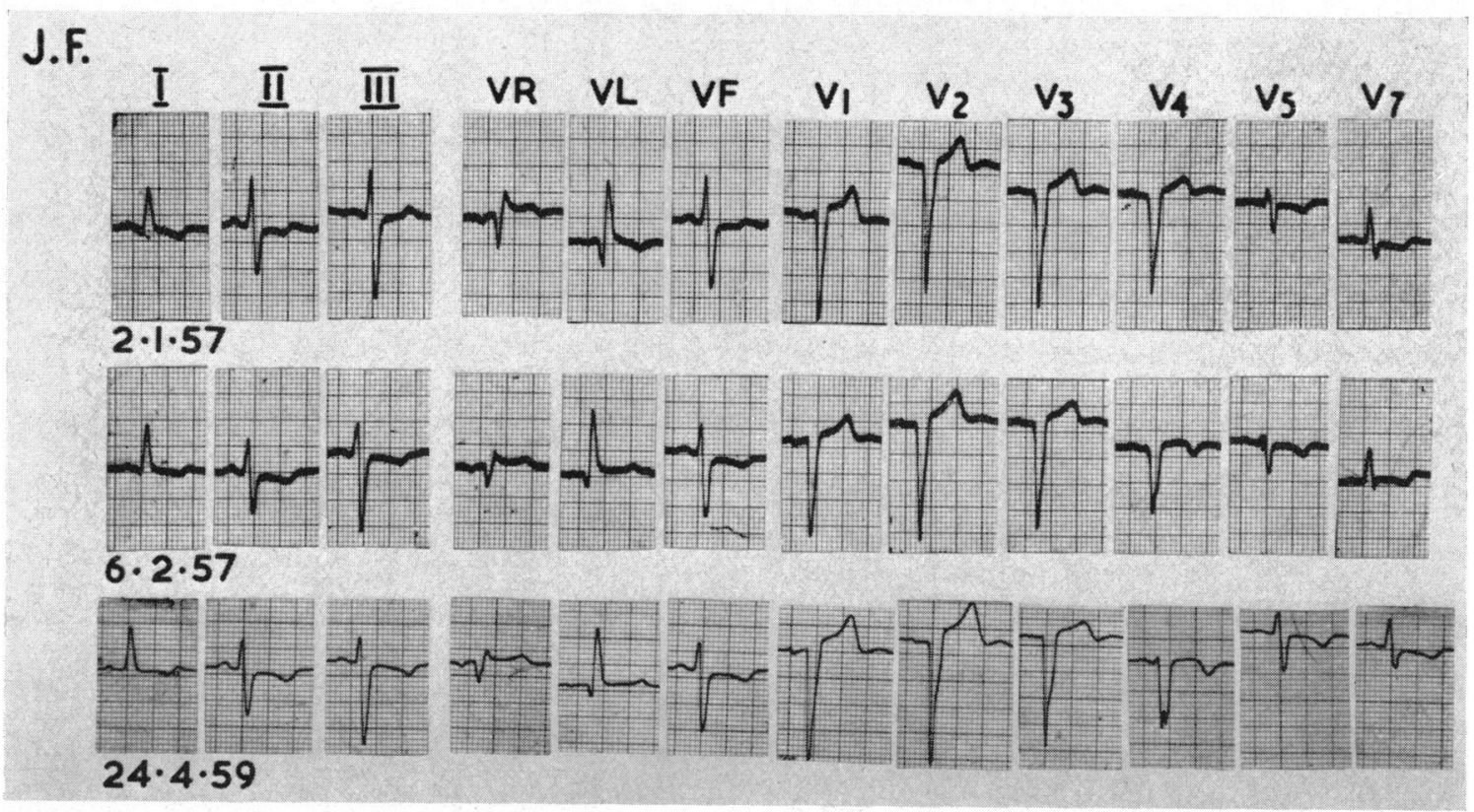

FIG. 8.-Serial tracings of Case 11. Reversal of direction of $T$ wave. Changing $T$ wave axis and deepening of $\mathbf{R}-\mathbf{T}$ depression in posterolateral leads during status anginosus lasting $2 \frac{1}{2}$ years. Involvement of right coronary artery after occlusion of the left anterior coronary artery ten years previously, as shown by scar of transmural anteroseptal infarct.

Case 3. The findings were those of considerable concentric hypertrophy of the wall of the left ventricle. There were small infarctions of recent origin within the substances of some of the papillary muscles and one or two small foci of similar nature in the wall of the ventricular cavity itself (Fig. 10). The distribution of the foci was subendocardial in the papillary muscles (Fig. 11). In addition small areas of interstitial fibrosis were present in many parts of the ventricular myocardium. There was severe atheroma of the main coronary arteries and of their larger branches, and considerable arteriosclerosis of the smaller vessels within the myocardium. No ante-mortem thrombus was found in any of the coronary branches.

\section{Discussion}

These results confirm that most patients with periods of repetitive severe angina show persistently the electrocardiographic pattern seen transiently in angina of effort and after the exercise test. Thus the term status anginosus as a clinical entity is further strengthened by the electrocardiographic background.

The pathological basis in three of our cases with necropsy control was that of subendocardial infarction, as found by others, with involvement of the papillary muscles in two, a point made by Horn et al. (1950). These areas of focal necrosis, which give the myocardium a mottled appearance, leave healthy or less injured zones in between; this may explain the cardiographic changes and also their erratic distribution in various leads. Fulton (1956) emphasized that the necrosis is not strictly subendocardial but rather involves the inner shell of the left ventricular mycardium leaving a thin strip of subendocardial myocardium intact; this can be clearly seen in Fig. 9 and 11 . The rarity of bundle-branch block, partial or complete, in subendocardial infarction is in accordance with these findings since the bundle branches course superficially. Cook et al. (1958) in an extensive pathological study have proved that, only if the infarct involves half or three-quarters of the inner thickness of the left ventricular wall, will the electrocardiographic pattern of transmural infarct result. In thin, shell-like infarcts, involving less than half of the inner thickness of the left ventricle and about 


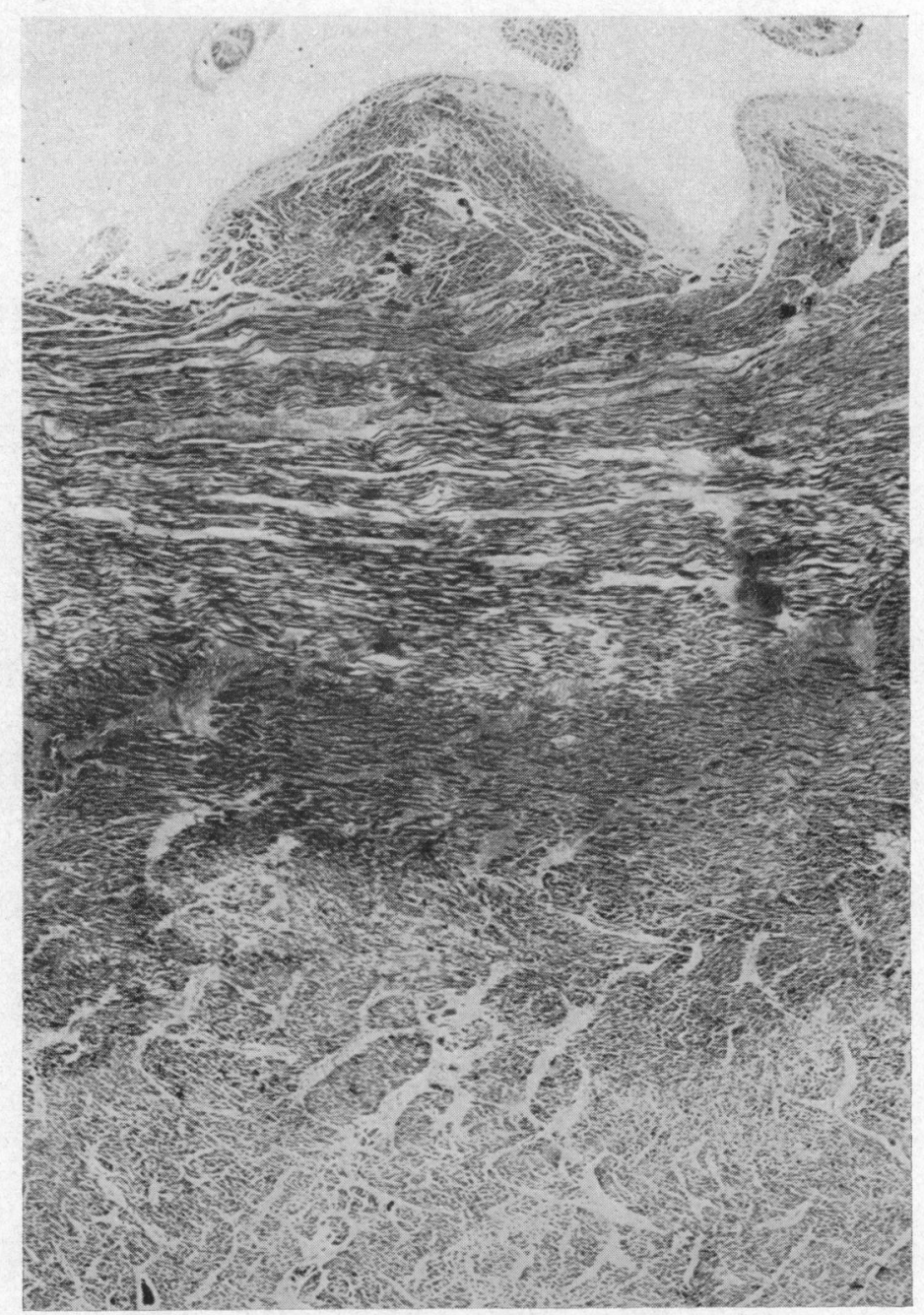

FIG. 9.-Photomicrograph of section of the posterior wall of the left ventricle in Case 2 , showing subendocardial infarct of the inner half of the myocardium. This is bounded by a zone of dense polymorphonuclear infiltration (dark area) separating it from normal myocardium. The endocardium and a small band of underlying muscle fibres are intact, as are also the outer and subepicardial areas of the myocardium.

half of its circumference, no Q waves will appear (Fig. 1). In fact, the electrocardiographic picture of subendocardial ischæmia will be indistinguishable from that of subendocardial infarction except by its persistence. A gradual reversion to normal after weeks (Fig. 3) may not invalidate a diagnosis of patchy subendocardial infarction, since small fibrotic scars in the inner shell of the left ventricle surrounded by healthy myocardium may not show in the record. Small focal subendocardial infarcts may also produce œedema or injury of the overlying subepicardial areas causing temporary deep inversion of $\mathrm{T}$ waves which may mask $\mathrm{R}-\mathrm{T}$ segment depression. With regression of the infarct, the signs of subepicardial injury disappear and the cardiogram may revert to near normal as in "slight coronary attacks" (Papp and Shirley Smith, 1951). The pattern of 


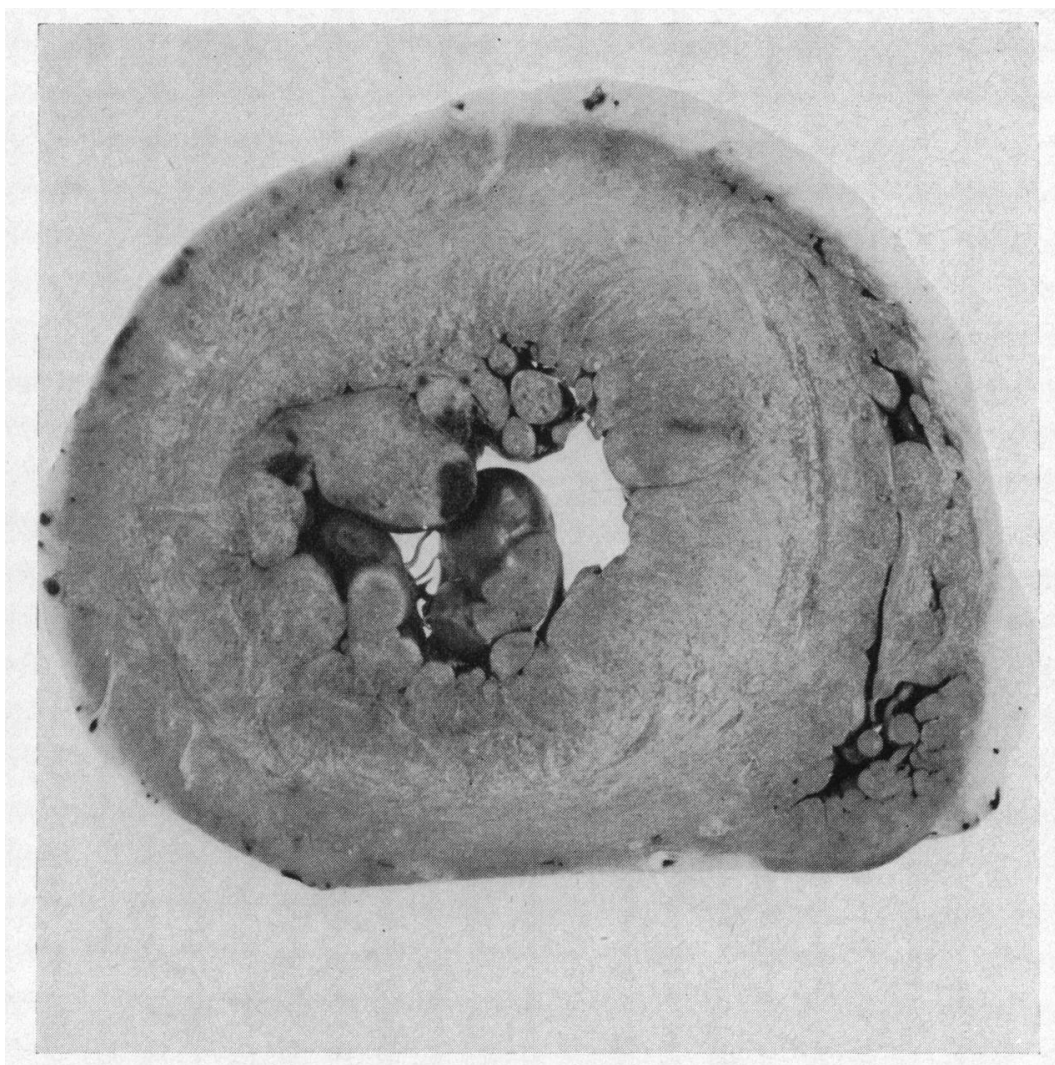

FIG. 10.-Horizontal section of the heart in Case 3, showing concentric hypertrophy of left ventricle, infarction of papillary muscles (dark areas), and minute areas of subepicardial infarction.

subendocardial infarction may become apparent only after the regression of subepicardial injury as seen in five patients in the present series.

In the face of this ample pathological evidence Prinzmetal et al. (1959) were unable to bring any experimental proof that $\mathrm{R}-\mathrm{T}$ segment depression originates in the subendocardial areas. Whereas in anginal patients undergoing Beck's operation, they found "islands" of $\mathbf{R}-\mathbf{T}$ depression in direct epicardial leads; in dogs rendered hypotensive by bleeding, with similar findings in epicardial leads, the subendocardial areas explored with plunge electrodes failed to show any segmental shift. How far experimental conditions in dogs, which may simulate but not reproduce pathological events in patients, can invalidate post-mortem evidence remains doubtful. It may well be that it is not so much the location of the lesion as the existence of myocardial injury of varying degree, side by side with relatively healthy myocardium, that is mainly responsible for the segmental shift in the cardiogram, well known to occur over zones adjacent to infarcted areas.

The coronary circulation in four cases of gradually worsening angina was studied by Fulton (1956) with injection technique. He demonstrated a dense network of anastomotic channels in the subendocardial areas as a consequence of severe narrowing or occlusion of one or both coronary arteries. It is in this "zone" that focal necrosis ultimately develops: this feature distinguishes the "inner zone" or subendocardial infarction from the "regional" infarct which is the consequence of sudden occlusion of a major coronary branch. According to Bedford (1958) non-transmural subendocardial infarction may occur in either circumstance. The subendocardial areas are specially vulnerable because of their remoteness from the source of blood supply, the extra work imposed upon the papillary muscles, the poorer blood supply of the endocardium as compared to the epicardium, 


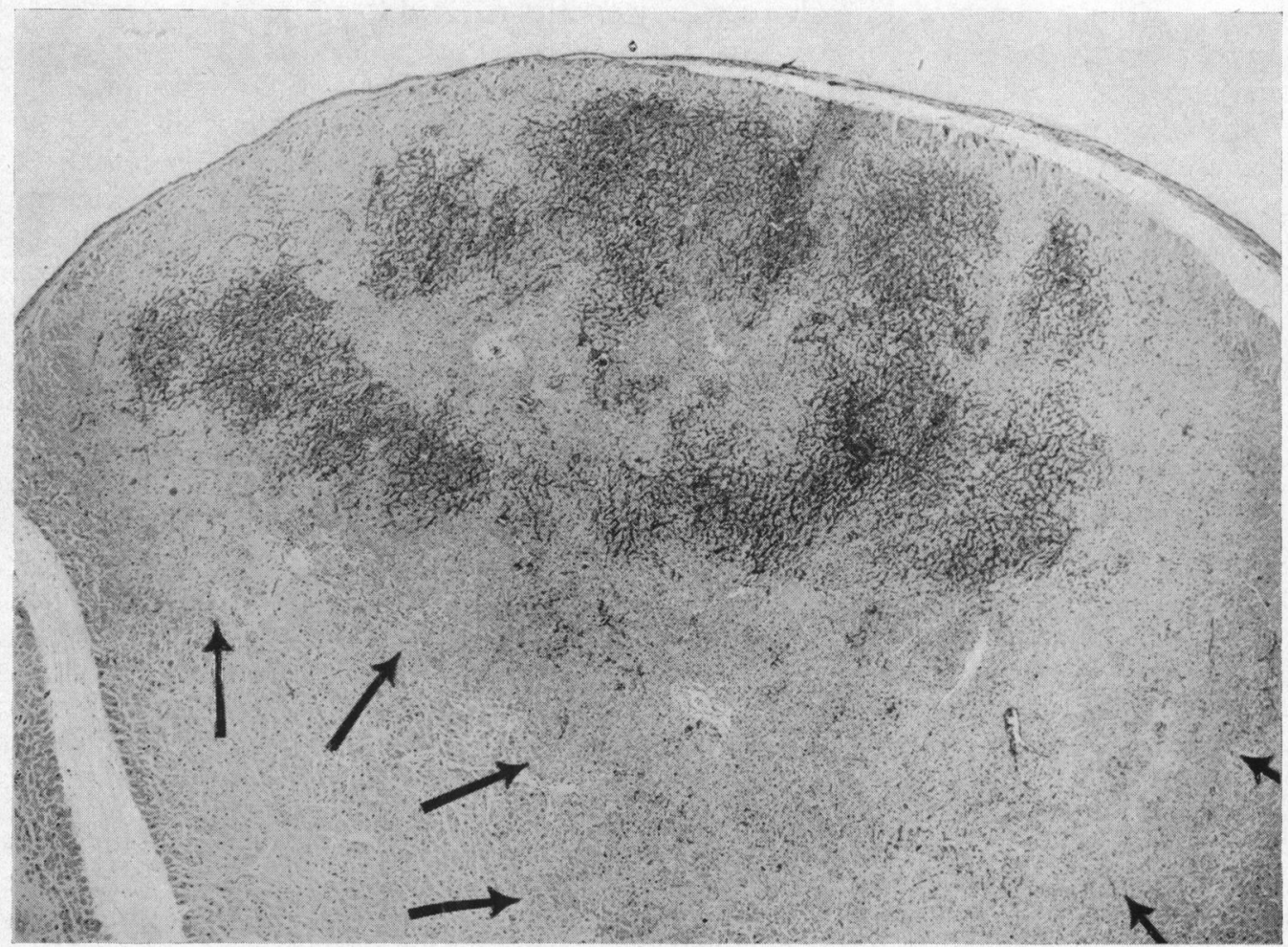

FIG. 11.-Photomicrograph of section of infarcted papillary muscle of Case 3. The arrows indicate the boundary between the infarction and healthy myocardium; the latter also extends as a thin subendocardial zone on each side of the infarct. Dark areas represent zone of polymorphonuclear infiltration. Mayer's hæmalum and eosin. $(\times 25)$.

and the high intramural pressure during systole which may exceed the aortic pressure (Horn et al., 1950).

The evolution of coronary disease is dependent on two factors, that of thrombosis and that of arteriosclerosis. These influences are inter-related and the course of the malady may depend on the preponderance of one or the other. An increased tendency to blood clotting in patients with coronary heart disease has recently been shown to exist, with a gradient from angina of effort and "coronary insufficiency" to cardiac infarction. Thus coagulability of blood was found to be higher in patients with cardiac infarction than in those with angina pectoris (McDonald and Edgill, 1950). In the majority of our patients the disease evolved gradually during the course of years from angina of effort, without the occurrence of major infarction, into status anginosus; in these cases necropsy examination showed extreme narrowing of the coronary arteries, but no thrombosis (Cases 1 and 3 ) or thrombosis as the final episode in a greatly restricted coronary circulation (Case 2). They belonged to the arteriosclerotic variety of coronary disease. When the two factors acted in sequence, thrombosis of a major coronary branch was the initial manifestation; after a symptomless period of months or years status anginosus developed by reason of gradually worsening coronary circulation in the territory of the other branch. When the two factors acted together status anginosus led to a major infarct within a short time.

The pattern of subendocardial ischæmia may remain unchanged even after severe bouts of angina: since the development of the pattern of transmural infarction is unusual, one may be induced to look for an extra-cardiac cause or to dismiss the pain as unimportant, all the more as it is unresponsive to trinitrin. Thus a serious diagnostic difficulty may arise. The greatly restricted coronary 
circulation, with the lumen of the major coronary arteries reduced to pin point size, explains these prolonged attacks. No help is forthcoming from collateral circulation as the pressure is low in both coronary arteries. It is only through the redistribution of blood through the subendocardial network that the oxygen needs of the heart muscle can be precariously maintained. The sudden deepening of R-T depression or its increasing slope or its transformation from the flat into the square pattern are the signs of grave involvement of the subendocardial areas. When these signs appeared in our patients the clinical state became worse; six out of eight of such cases died within days or weeks. The reversal of such a record to normal was exceptional, being seen only once. In contrast with prolonged congestive heart failure following major coronary occlusion and classical infarction, sudden urgent dyspnœa with congestion often heralds the approach of death in these patients.

\section{TREATMENT}

This is a condition in which spontaneous remission is a feature of the clinical course; this makes the assessment of the results of any treatment very difficult (Table II). The only specific treatment adopted was by anticoagulants, which might be continued as a long-term measure. Thyroid suppression by thiouracil derivatives or radio-iodine treatment produced benefit on occasion. The euphoric effects of iproniazid or of its less toxic homologue nialamide were frequently helpful. Long-acting nitrite preparations were useful in rare instances. Hydrochlorothiazide was successfully employed against nocturnal angina. As an analgesic pethidine by injection combined with chlorpromazine or promethazine proved to be superior to morphine. Such small experience as we have had of talc insufflation into the pericardium and of sympathectomy has not been encouraging.

\section{SUMMARY}

Status anginosus is a clinical term denoting periods of frequently recurring anginal pain at rest, alleviated by trinitrin briefly or not at all, and indistinguishable from the pain of cardiac infarction or from its prodromal manifestation, but without the electrocardiographic and laboratory evidences of classical cardiac infarction.

In a series of twenty patients the syndrome developed insidiously from angina of effort and gradually increased in severity into a state in which decubital angina became the main feature. Periods of frequently recurring night attacks alternated with periods of relative freedom. Cardiac infarction developed within weeks or months in half of the patients; in others status anginosus might persist for months or years.

The common electrocardiographic features were those of subendocardial ischæmia with sloping or square R-T depression which persisted until or deepened before death. Q waves never appeared and reversion of the record to normal was exceptional. Uncommon features were changing direction of $T$ waves and the R-T elevation of the acute injury pattern. It was considered that the resemblance to the pattern of the positive exercise test in angina of effort further justified the term status anginosus.

Necropsy studies in three cases showed subendocardial infarction caused by severe arteriosclerotic narrowing of the main coronary arteries. Thrombosis as a secondary or terminal manifestation occurred in only one of them.

Status anginosus is the clinical counterpart of progressive arteriosclerotic narrowing of the main coronary branches so that a precarious myocardial supply can only be maintained by redistribution of blood through the subendocardial network evolved as the consequence of generalized ischæmia. Once this area becomes involved, the state of the patient worsens; the electrocardiogram shows deepening R-T depression, but no signs of major infarction. Death may be sudden during an attack of pain or more gradual with rapidly progressing left ventricular failure.

Treatment is essentially symptomatic and does not materially alter the course of the disease.

We are indebted to Prof. William Symmers and Dr. J. H. Shore for the necropsy and photographs of Case 3, to Dr. L. J. Grant for the necropsy findings in Case 1 and the follow-up of Case 9, and to Dr. Janet E. Arnott for the necropsy and microphotographs of Case 2. We thank also Miss Anne Smith, Miss Pat Turnbull and Mrs. M. P. Roche of the Charing Cross Hospital for their valuable cardiographic, photographic, and secretarial assistance. 


\section{REFERENCES}

Bedford, D. E. (1958). 3rd Congrèss Mondial de Cardiologie, Bruxelles. $\quad$ Abstract of symposia. p. 314.

Chevalier, H., and Simon, J. (1959). Amer. Heart J., 58, 120.

Cook, R. W., Edwards, J. E., Pruitt, R. D. (1958a). Circulation, 18, 603.

,$--(1958 b)$. Circulation, 18, 613

Fulton, W. F. M. (1956). Brit. Heart. J., 18, 341.

Herrick, J. B. (1912). J. Amer. med. Ass., 59, 2015.

Horn, H., Field, L. E., Dack, S., and Master, A. M. (1950). Amer. Heart. J., 40, 63.

Levine, S. A. (1958). Clinical Heart Disease. 5th ed. W. B. Saunders Co. Philadelphia, London.

Levine, M. D., and Ford, R. V. (1950). Circulation, 1, 246.

McDonald, L., and Edgill, M. (1959). Lancet, 1, 1115.

Master, A. M. (1958). Amer. Heart. J., 56, 570.

Gubner, R., Dack, S., and Jaffe, H. L. (1941). Arch. intern. Med., 67, 647.

Obrastzow, W. P., and Straschesko, N. D. (1910). Ztschr. klin. Med., 71, 116.

Papp, C., and Shirley Smith, K. (1951). Brit. Heart J., 13, 17.

Price, R. K., and Janes, L. R. (1943). Brit. Heart J., 5, 134.

Prinzmetal, M., Goldman, A., Shubin, H., Bor, N., and Wada, T. (1959). Amer. Heart. J., $57,531$.

Reeves, J. T., and Harrison, T. R. (1956). J. Chron. Dis., 4, 340.

Scherf, D., and Golbey, M. (1954). Amer. Heart. J., 47, 928.

Yu, P. N. G., and Stewart, I. M. (1950). Amer. Heart. J., 39, 862. 